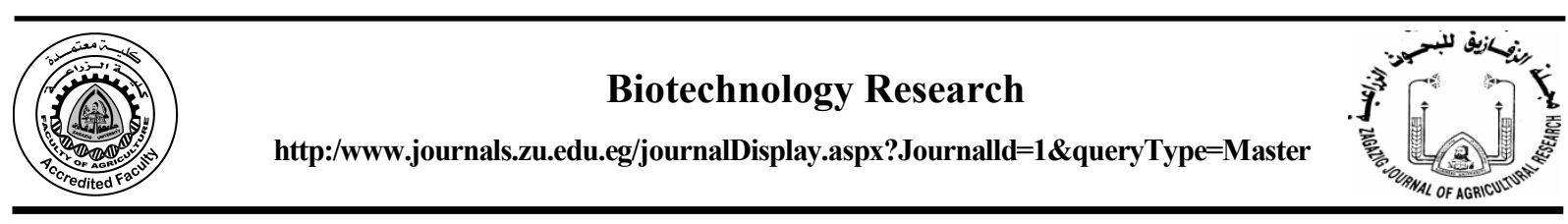

\title{
PURIFICATION AND SPECIFICATION OF BACTERIOCIN PRODUCED BY SOME Lactobacillus SPP. ISOLATED FROM FOOD
}

\author{
Nadeen G. Mostafa ${ }^{*}$, E.M. Gewaily, Fatma I. El-Zamik and A.S. Ali \\ Agric. Microbiol. Dept., Fac. Agric., Zagazig Univ., Egypt
}

Received: 03/02/2019 ; Accepted: 20/02/2019

\begin{abstract}
A total of 20 isolates of lactic acid bacteria (LAB) were isolated anaerobically from different food sources (Domiati cheese; raw milk and mixed pickles). Three out of 20 isolates showed high inhibition of growth pathogenic bacteria by well diffusion assay method and therefore they were chosen for bacteriocin production and further studies. The selected isolates were identified based on morphological, biochemical and MALDI-TOF mass spectrometry. All of the tested species gave a score value between 2.116 to $2.165(100 \%)$ were correctly identified by MALDI-TOF- MS to the genus and species levels. They were identified as L. brevis, L. plantarum and L. fermentum. The bacteriocin was purified by salt precipitation and gel chromatography methods. The molecular weight was determined by SDS-PAGE and amino acid composition was also analysed. The purified bacteriocin was characterized and found to be thermostable at temperatures up to $90^{\circ} \mathrm{C}$ for $30 \mathrm{~min}, \mathrm{pH}$ from 3 to 11 and its activity improved in the presence of Tween 80, SDS and EDTA. The contents of bacteriocin from the acidic amino acid residues aspartic + glutamic (asp+glu) were $0.74 \%$ for all tested samples. The contents of the basic amino acids argnine + lysine + hisitidine ( $\arg +$ lys + his $)$ were $0.23 \%$ for all the tested samples.
\end{abstract}

Key words: Lactic acid bacteria, bacteriocin, stability, gel chromatography, Lactobacillus, antimicrobial activity, amino acid.

\section{INTRODUCTION}

Lactic acid bacteria (LAB) are widely used in food industry as starter culture for fermentation. Lactobacilli have been used since decades against infectious diseases (Bernet et al., 1994) and have been extensively studied for their ability to protect against pathogenic bacteria. These organisms have been widely used as probiotics (Tannock, 1999; Sgouras et al., 2004).

Many of these lactic acid bacteria are known to produce antibacterial substances including bacteriocins which can inhibit the growth of several pathogenic bacteria. Bacteriocins from lactic acid bacteria are natural antimicrobial peptides or small proteins with bactericidal or bacteriostatic activity against genetically closely related species (Klaenhammer, 1988). Bacteriocins can be classified broadly as those synthesized by Gram-positive and those by Gram-negative

\footnotetext{
Corresponding author: Tel. : +201099151262

E-mail address: nadeengamal1987@gmail.com
}

bacteria. Among those synthesized by Grampositive bacteria, lactobacilli bacteriocins are of commercial value (Garneau et al., 2002).

Lactobacillus bacteriocins are found within each of the four major classes. Class: I bacteriocins (antibiotics) were discovered in the Lactobacillaceae by (Mortvedt et al., 1991). These bacteriocins are small membrane-active peptides $(<5 \mathrm{kDa})$ containing an unusual amino acid, lanthionine. The class: II bacteriocins are less heatstable, non-lan- thionine containing and membrane-active peptides $(<10 \mathrm{kDa})$. The class: III bacteriocins have been found in Lactobacillus, include heat labile proteins of large molecular mass. The class: IV bacteriocins are a group of complex proteins, associated with other lipid or carbohydrate moieties, which appear to be required for activity. They are relatively hydrophobic and heat stable (Karaoğlu et al., 2003). 
Several types of bacteriocins from foodassociate lactic acid bacteria have been identified and characterized (Ravi et al., 2011). Because of the increasing demand for more natural and microbiologically safe food products, there is a need for biopreservation methods. Bacteriocins have considerable potential for food preservation, as well as for human therapy as a potential supplements or replacements for currently used antibiotics (Fricourt et al., 1994; Ogunbanwo et al., 2003).

Different bacteriocin exhibits different inhibition profile on food spoilage and pathogenic microorganisms. Therefore, they could be natural replacements for synthetic food preservatives (Ennahar et al., 1999). In order to increase the productivity of bacteriocins, a better understanding of factors affecting their production is essential. Bacteriocin production has been reported to be affected by several factors including carbon and nitrogen sources; and fermentation conditions, such as $\mathrm{pH}$, temperature and agitation (Ennahar et al., 1999).

Therefore, the present study aimed to purify and characterize the bacteriocin produced from Lactobacillus spp.

\section{MATERIALS AND METHODS}

\section{Isolation of Lactic Acid Bacteria from Different Sources}

Lactic acid bacteria (LAB) were isolated from domiati cheese, raw milk and mixed pickles. The samples were collected from supermarket in Zagazig city during 2018 using sterile bottles and stored in an ice box until delivering to the laboratory of Agric. Microb. Dept., Fac. Agric, Zagazig University, Egypt for analysis. One gram $/$ milliliter of each sample was diluted in $0.9 \%$ sterile saline solution to a final volume of $10 \mathrm{ml}$ and $0.1 \mathrm{ml}$ of each dilution was plated on selective MRS- medium (DeMan ,Rogosa-Sharpe, Oxoid, CM 361). The $\mathrm{pH}$ of the medium was adjusted to 6.5 , using a digital electrode $\mathrm{pH}$ meter. Plates were incubated at $37 \pm 2^{\circ} \mathrm{C}$ anaerobically in jars with AnaeroGen sacks (Oxoid,UK) for $48 \mathrm{hr}$. After incubation, different colonies were randomly collected from each sample, the selected colonies were purified by streak plate technique. The purified bacterial isolates were stored in MRS broth at $4^{\circ} \mathrm{C}$ for further studies (De- Man et al., 1960).

\section{Preliminary Identification of Lactic Acid Bacteria}

Morphological and biochemical characters were used to identify the most acid resistant bacteria isolates according to Logan and De Vos (2009). The following tests were performed: cell morphology, Gram reaction, catalase test, growth at $10^{\circ} \mathrm{C}$ for 5 days and $45^{\circ} \mathrm{C}$ for $48 \mathrm{hr}$. in MRS- broth, salt tolerance ( $4 \%$ and $6.5 \% \mathrm{NaCl}$ in MRS- broth). Sugar fermentation tests were applied using glucose, lactose, mannitol, galactose, D- cellobiose, raffinose, D-trehalose and sucrose.

\section{MALDI-TOF-MS Profile Method}

Identification of $\mathrm{LAB}$ had been confirmed by using matrix-assisted laser desorption/ionization time of flight mass spectrometry (MALDI-TOFMS) in peptide and protein analyses.

One large colony from each of selected bacterial isolate (enough to fill about one half of a $10-\mu 1$ inoculating loop) was suspended in $70 \%$ ethanol in a $1.5 \mathrm{ml}$ microcentrifuge tube and loaded three times onto ground steel MALDI target according to the manufacturer's instruction (Bruker Daltonics, Breman, Germany). Matching between experimental MALDI-TOF-MS profiles obtained from bacterial isolates and the reference MALDI-TOF-MS profiles is expressed by a BioTyper according to a $\log$ (score) and an associated-color code (green, yellow and red). Briefly, a BioTyper log (score) exceeding 2.3 (green color) indicates a highly probable identification at the species level. A Log (score) between 2.0 and 2.3 means highly probable identification at the genus level (green color) and probable identification at the species level. A Log (score) between 1.7 and 2.0 (yellow color) implies only probable genus identification, while score value under 1.7 (red color) means no significant similarity between the unknown profile and any of those of the database. Micro Flex mass spectrometeries were performed at Academic Park, Faculty of Medicine, Alexandria, University, Egypt, according to Biswass and Rolain (2013) as well as Nacef $\boldsymbol{e t}$ al. (2016). 


\section{Partial Purification of Bacteriocin}

A $250 \mathrm{ml}$ of MRS- broth was inoculated with $1 \%$ overnight inoculum of the isolate and incubated at $37^{\circ} \mathrm{C}$ for $18 \mathrm{hr}$. The cells were separated by centrifuging the broth at 10,000 $\mathrm{rpm}$ for $10 \mathrm{~min}$ at $4^{\circ} \mathrm{C}$. The crude bacteriocin substances was partially purified by salt saturation method using ammonium sulphate to precipitate out proteins. The crude bacteriocin was stirred using a magnetic stirrer with the addition of ammonium sulphate slowly till saturation point of $70 \%$ reaching at a temperature of $4^{\circ} \mathrm{C}$. The precipitated proteins were separated by centrifugation at $10,000 \mathrm{rpm}$ for $20 \mathrm{~min}$ at $4^{\circ} \mathrm{C}$. The protein pellet obtained was dissolved in $1 \mathrm{M}$ phosphate buffer of pH 7.0 (Vera et al., 2012).

\section{Gel Chromatography}

This analysis was held at Agric. Biochemistry, Dept., Fac., Agric., Zagazig Univ. Sephadex G25 was used as a column to purify (desalt) the salt precipitated protein. The gel column was pre equilibrated with $0.1 \mathrm{M}$ Tris $\mathrm{HCl}$ buffer $(\mathrm{pH} 7)$, $10 \mathrm{ml}$ of the precipitated protein dissolved in phosphate buffer previously was added onto the column without disturbing the gel. The proteins were eluted with $0.1 \mathrm{M}$ Tris $\mathrm{HCl}$ buffer $(\mathrm{pH} 7)$ and sample fractions of $1 \mathrm{ml}$ were collected in eppendoff tubes by setting the flow rate to 15 $\mathrm{ml} / \mathrm{hr}$. (Ravi et al., 2012).

\section{Molecular Weight Determination of Protein by SDS PAGE}

This analysis was held at Agric. Biochemistry, Dept., Fac., Agric., Zagazig Univ., An amount of bacteriocin from lactic acid bacteria $(10 \mathrm{mg})$ was dispersed in $1 \mathrm{ml}$ SDS $10 \%$ with $100 \mu 1 \beta$-mercaptoethanol for $15 \mathrm{~min}$ with vortexing every $5 \mathrm{~min}$. The extract was centrifuged at 10,000 rpm for 10 min (Osman et al., 2018). A mixture of $20 \mu 1$ extract and 20 $\mu \mathrm{l}$ of SDS-loading sample buffer (SDS $4 \%, \beta$ mercaptoethanol $3 \%$, glycerol $20 \%$, Tris $\mathrm{HCl} 50$ $\mathrm{mM} \mathrm{pH} 6.8$ and bromophenol blue traces), was heated at $96^{\circ} \mathrm{C}$ for $3 \mathrm{~min}$ and $10 \mu \mathrm{l}$ aliquot (per lane) was electrophoresed by SDS-PAGE according to (Laemmli, 1970).

\section{Bacteriocin Assay}

The antibacterial activity of the bacteriocin isolated from Lactobacillus spp. was determined using the well diffusion method as described by Ivanova et al. (2000) against 2 pathogenic bacteria Gram positive Staphylococcus aureus ATCC 43300 and Gram negative E. coli, which was kindly provided by the Dept. of Microbiology, Faculty of Medicine, Alex. Univ. $50 \mu \mathrm{l}$ of the bacteriocin were placed in $5-\mathrm{mm}$ diameter wells that had been cut in nutrientagar plates previously seeded with the indicator bacteria. The plates were incubated at $37^{\circ} \mathrm{C}$ for $24 \mathrm{hr}$. After incubation, the diameter of zone of growth inhibition was measured.

\section{Stability of Bacteriocin at Different pH and Temperature Degrees}

\section{Effect of $\mathrm{Ph}$ level}

To determine the effect of $\mathrm{pH}, 0.5 \mathrm{ml}$ of purified bacteriocin was added into $4.5 \mathrm{ml}$ of nutrient- broth at different $\mathrm{pH}$ values (3 to 11) and incubated for $30 \mathrm{~min}$ at $37^{\circ} \mathrm{C}$. Each of the bacteriocin samples treated at different $\mathrm{pH}$ values was assayed against indicator bacteria by well diffusion method (Motta and Brandelli, 2002; Sharma and Gautam, 2007).

\section{Effect of different temperatures}

Purified bacteriocin $(0.5 \mathrm{ml})$ was added into $4.5 \mathrm{ml}$ of nutrient- broth in the test tube. Each test tube was then overlaid with paraffin oil to prevent evaporation and then incubated at different temperatures $(30,40,50$ and 60,70 , 80,90 and $100^{\circ} \mathrm{C}$ ) for $30 \mathrm{~min}$. The preparations containing nutrient- broth $(4.5 \mathrm{ml})$ and bacteriocin $(0.5 \mathrm{ml})$ in test tubes were plugged with nonabsorbent cotton and covered with aluminum foil and kept in an autoclave at $121^{\circ} \mathrm{C}$ for $15 \mathrm{~min}$ to check its activity at very high autoclaving temperature. The bacteriocin activity of above different heat-treated was measured by well diffusion method (Sharma $\boldsymbol{e t}$ al., 2006)

\section{Effect of surfactants}

The effect of surfactants on the bacteriocins was tested by adding SDS, EDTA and Tween 80 individually $(0.5 \% \mathrm{~V} / \mathrm{V}$ final concentration $)$, to bacteriocins and untreated bacteriocin preparation was used as positive control. All samples were incubated at room temperature for $2 \mathrm{hr}$., then tested for residual antibacterial activity by well diffusion method (Sivaramasamy et al., 2014). 


\section{Amino Acid Analyzer}

This experiment was held at Regional Centre for Food and Feed, Research Center, Ministry of Agriculture. Total amino acids composition in lyophilized crude extract of bacteriocin of $L$. brevis, L. plantarum and L. fermentum were determined by amino acid analyzer apparatus model "Eppendorf LC3000" (Simpson et al., 1976) using the following steps: Bacteriocin crude extract from production media, $10 \mathrm{ml}$ of sample were taken and centrifuged at $10,000 \mathrm{rpm}$ for 10 min. the supernatant was collected and lyophilized. A known weight $0.2 \mathrm{~g}$ from lyophilized crude extract of bacteriocin of each sample was received $10 \mathrm{ml} 6 \mathrm{~N}$ hydrochloric acid in a sealing tube, and then placed in oven at $110^{\circ} \mathrm{C}$ for $24 \mathrm{hr}$. Hydrolysates were transferred quantitatively into a porcelain dish and the hydrochloric acid was then evaporated to dryness at $50-60^{\circ} \mathrm{C}$ on a water bath. Distilled water $(5 \mathrm{ml})$ was added to the hydrolysate and then evaporated to dryness to remove the excess of hydrochloric acid and finally the residue was dissolved in $10 \mathrm{ml}$ distilled water and filtrate through $0.45 \mathrm{Mm}$ filter. The filtrate was dried under vacuum with a rotary evaporator, then 10 $\mathrm{ml}$ of distilled water were added and the samples were dried a second time. One $\mathrm{ml}$ of $0.2 \mathrm{~N}$ sodium citrate buffer at $\mathrm{pH} 2.2$ was added and the samples were stored frozen in a sealed vial until separation of amino acids by amino acid analyzer [Column: hydrolysate column Eppendorf LC $3000(250 \times 4.6)]$. The temperature of amino acid analyzer was $47^{\circ} \mathrm{C}$; Sample: $20 \mu \mathrm{l}$; Buffer system: Sodium acetate, buffer A ( $\mathrm{pH} 3.3$ ), buffer B (pH 3.6), buffer $\mathrm{C}(\mathrm{pH} 4.3)$ and buffer $\mathrm{D}$ (pH11.0); Flow rate: $0.2 \mathrm{ml} / \mathrm{min}$.). Ninhydrin was used for the detection of amino acids at 440 $\mathrm{nm}$ for proline and $570 \mathrm{~nm}$ for the other amino acids through an oxidative decarboxylation reaction. The peak area and percentage of each amino acid were calculated by computer software AXXIOM CHROMATOGRAPHY- 727.

\section{RESULTS AND DISCUSSION}

\section{Isolation and Preliminary Screening of Isolated LAB}

A total of 20 isolates were isolated from domiati cheese, raw milk and mixed pickles as shown in Table 1. Most of them were characterized as Gram positive, catalase negative and non spore forming bacteria. From the preliminary screening only 3 isolates out of 20 were selected based on their high activity for inhibition of pathogenic bacteria. These 3 isolates were then identified using phenotypic and biochemical methods and subjected to in vitro characterization to purify bacteriocin from them.

\section{Identification of the Selected Isolates}

Morphological and biochemical characteristics were used to identify the 3 selected isolates (Table 2) according to (Logan and De Vos, 2009). Gram positive and catalase negative isolates were considered as presumptive LAB. All the isolates were Gram positive, catalase negative and non-spore forming, negative for gas production from glucose. According to morphological and biochemical tests the isolates $\mathrm{R} 3$ and M5 grew at $10^{\circ} \mathrm{C}$ except isolate D2 which grew at $45^{\circ} \mathrm{C}$. All isolates tolerated $4 \%$ of $\mathrm{NaCl}$ concentration. Concerning growth at $6.5 \%$ $\mathrm{NaCl}$, strain $\mathrm{R} 3$ folerated it but M5 and D2 did not. All the isolates fermented lactose and sucrose which showed various fermentation levels to other carbohydrates. Based on these results, isolates R3 tend to be Lactobacillus brevis, M5 Lactobacillus plantarum and D2 Lactobacillus fermentum.

\section{Direct Identification of the Tested Bacteria Using MALDI-TOF-MS}

The above mentioned isolates were identified at Academic Park Fac. Medicine Alex. Univ., Egypt, using MALDI-TOF-MS. (matrix-assisted lazer desorption ionization-time of flight mass spectrometry). This strategy is becoming a method of choice for determining the genus, species and even subspecies of bacterial isolates (Carbonnelle et al., 2012; Dušková et al., 2012). Also, this strategy is achievable for other microorganisms (e.g. yeasts, fungi,) from various sources (Chalupová et al., 2014). Using this advanced method, the identification was confirmed and the prospective strains were identical with their numbers as conserved in the International Cultural Center for Microorganisms. The score values for the bacterial isolates are shown in Table 3. All of the isolates showed a score value between 2.116 
Table 1. Number of LAB isolates and their sources

\begin{tabular}{lcc}
\hline Product abbreviation & No. of isolated LAB & Total percentage \\
\hline Domiati cheese (D) & 6 & 30 \\
Raw milk (R) & 7 & 35 \\
Mixed pickles (M) & 7 & 35 \\
Total & 20 & $100 \%$ \\
\hline
\end{tabular}

Table 2. Some morphological and biochemical characteristics of the selected LAB isolates

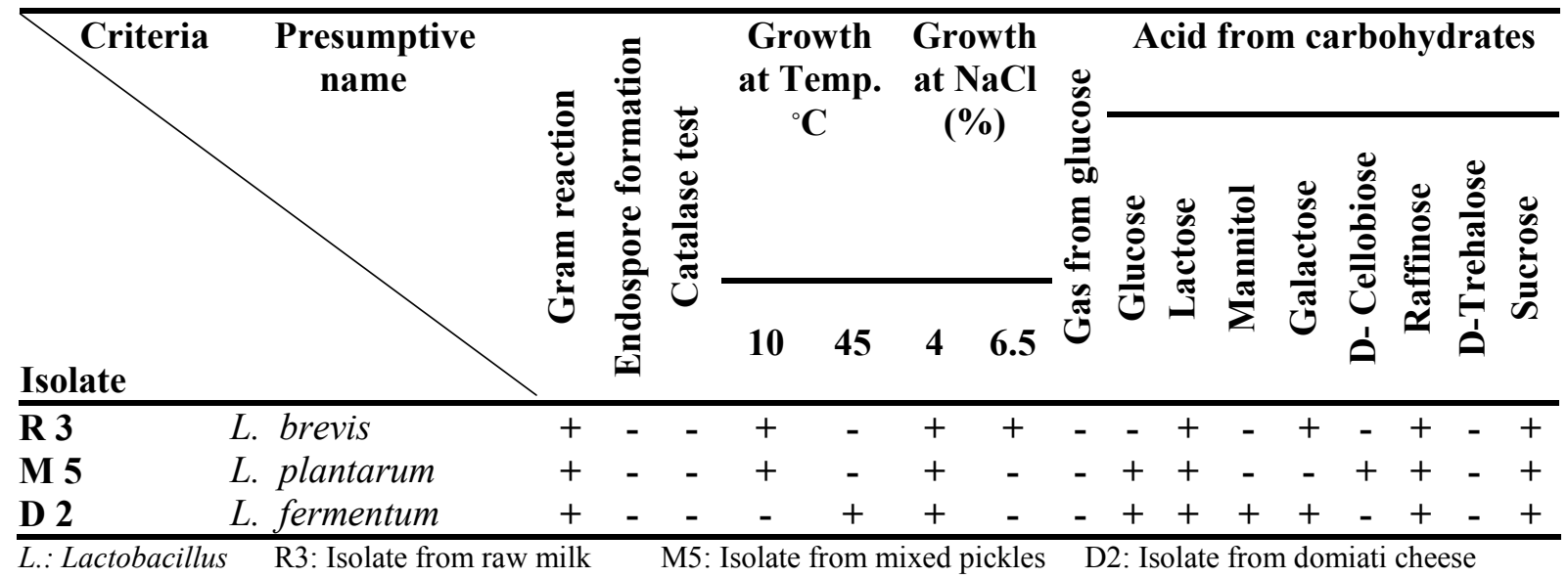

Table 3. Rate of classification results as determined by Bruker Daltonik MALDI Biotyper

\begin{tabular}{|c|c|c|c|}
\hline Isolate code & Analyte Name & Organism(best match) & ScoreValue \\
\hline $\mathbf{R 3}$ & $(++)(\mathbf{A}) \quad 1$ & Lactobacillus brevis_DSM 2647 DSM & 2.122 \\
\hline M7 & $(++)(A) I$ & Lactobacillus plantarum_DSM 2601 DSM & 2.116 \\
\hline D2 & $(++)(\mathbf{A}) 1$ & Lactobacillus fermentum_DSM_12341 DSM & 2.165 \\
\hline
\end{tabular}

- Category A= species consistency (2.300-3.000). DSM: Deutsche Sammlung von Mikroorganismen. 
to $2.165(100 \%)$ and were correctly identified to genus and species levels. All the tested bacterial strains were type strains that are included in the Bruker Database, and all spectrum scores were greater than 2.0. Thus, all of the tested LAB were correctly identified to genus and species levels with biotype software score values (Bizzini et al., 2010; Wang et al., 2013) greater than 2.0, and all of them had high degree of precision.

\section{Purification of bacteriocin}

The purification methods by using well diffusion assay method produced was summarized in Table 4. During the three stage of purification, a significant increase in bacteriocin purity and yield was observed. The susceptibilities of various Gram positive (Staph. aureus) and Gram negative (E. coli) bacteria to growth inhibition by bacteriocin produced by L. brevis, L. plantarum, L. fermentum were presented in Table 4 . It shows antibacterial activity against $E$. coli and Staph. aureus. Among these, highest growth inhibition was recorded against E. coli and moderate inhibition was observed against Staph. aureus. Similarity, bacteriocin from $L$. brevis showed high inhibition activity against $E$. coli and Staph. aureus in the three stages of purification. Bacteriocin from L. plantarum was found to be high active against pathogenic E. coli and Staph. aureus. Also bacteriocin from L. fermentum had high activity against $E$. coli and Staph. aureus in the stage of gel filteration. These results indicated that the presence of bacteriocin produced by the isolated lactic acid bacteria is responsible for their antimicrobial activity (Ravi et al., 2012).

\section{Molecular Weight of Protein by SDS PAGE}

The SDS-PAGE of bacteriocin produced from lactic acid bacteria are shown in Figure 1.The molecular weight was investigated by SDS-PAGE which showed a single band with an estimated molecular weight of $30 \mathrm{KDa}$ in comparison with protein marker.

\section{Stabitity of Bacteriocin at Different pH Values and Temperature}

$\mathrm{pH}$ and temperature have an important role in cell growth as well as bacteriocin production. Heat stability is considered an important character not only that makes them attractive in food industry, but also, it is an important factor in classifying bacteriocins. If a bacteriocin is considered as a bio preservative, it should be stable at a wide range of $\mathrm{pH}$ to overcome the effects of acids and alkalis in food and also heat stable which is an important criteria, since it should withstand the effect of heat during pasteurization, it should also retain its activity for a longer period which in turn will increases the shelf life to the preserved food.

\section{Effect of pH}

Bacteriocin was active in wide range of $\mathrm{pH}$, but the maximum activity was observed at $\mathrm{pH} 5$, 6,7 and 8 (Table 5). Bacteriocin could retain its antimicrobial activity partially when there was a shift to acidic or basic range. Stability of bacteriocin in different $\mathrm{pH}$ scale is a limiting factors for recommending its use in food items. Bacteriocin produced by L. brevis, L. plantarum and L. fermentum retained their antibacterial activity in an acidic $\mathrm{pH}$ of 5 and 6 , also in a basic $\mathrm{pH}$ range of 7 and 8 , while less activation

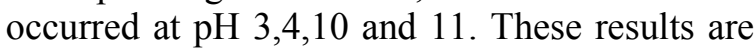
in a good agreement with those obtained by Sankar et al. (2012), Radha and Tallapragada (2015), Seema et al. (2015) and Sahar et al. (2017).

\section{Effect of temperature}

Different heat treatments were given to the bacteriocin to check its stability. The stability was assessed by noting the diameter of zone of inhibition after heat treatments. From Table 6, it can be noted that the bacteriocin produced by $L$. brevis, L. plantarum and L. fermentum was stable at temperatures ranging between $30^{\circ} \mathrm{C}$ to $80^{\circ} \mathrm{C}$ for period of $30 \mathrm{~min}$ which shows that the bacteriocin is thermostable in nature as it can withstand high temperature up to $121^{\circ} \mathrm{C}$ for 15 min. Thermostability of bacteriocin at high temperature makes it feasible to used foods which needs to be pasteurised before consumption. Highest activity was observed when it was heated at $60^{\circ} \mathrm{C}$ for $30 \mathrm{~min}$. and retained its activity up to $80^{\circ} \mathrm{C}$ for $30 \mathrm{~min}$. which shows that it is able to withstand pasteurization which is related to its molecular structure composed of small peptides with no tertiary structure as found by Parada et al. (2007) which is an important characteristic of a bio preservative. 
Table 4. Bacteriocin activivty of LAB strains, against Gram positive and Gram negative bacteria using well diffusion assay method

\begin{tabular}{|c|c|c|c|c|c|c|}
\hline \multirow{2}{*}{$\begin{array}{l}\text { Purification } \\
\text { stage }\end{array}$} & \multicolumn{2}{|c|}{ Culture supernatant (crude) } & \multicolumn{2}{|c|}{ Partial purification } & \multicolumn{2}{|c|}{ Gel filteration } \\
\hline & $\begin{array}{c}E \text {. coli } \\
\text { Diameter } \\
\text { inhibition } \\
\text { zone }(\mathbf{m m}) * \\
\end{array}$ & $\begin{array}{c}\text { Staph. aureus } \\
\text { Diameter } \\
\text { inhibition zone } \\
(\mathrm{mm}) \\
\end{array}$ & $\begin{array}{c}\text { E. coli } \\
\text { Diameter } \\
\text { inhibition } \\
\text { zone }(\mathbf{m m}) \\
\end{array}$ & $\begin{array}{c}\text { Staph. aureus } \\
\text { Diameter } \\
\text { inhibition } \\
\text { zone }(\mathrm{mm}) \\
\end{array}$ & $\begin{array}{c}E . \text { coli } \\
\text { Diameter } \\
\text { inhibition } \\
\text { zone }(\mathbf{m m}) \\
\end{array}$ & $\begin{array}{c}\text { Staph. aureus } \\
\text { Diameter } \\
\text { inhibition } \\
\text { zone (mm) } \\
\end{array}$ \\
\hline L. brevis & 21 & 17 & 25 & 25 & 29 & 29 \\
\hline L. plantarum & 19 & 17 & 22 & 21 & 26 & 23 \\
\hline L. fermentum & 17 & 16 & 20 & 19 & 26 & 25 \\
\hline
\end{tabular}

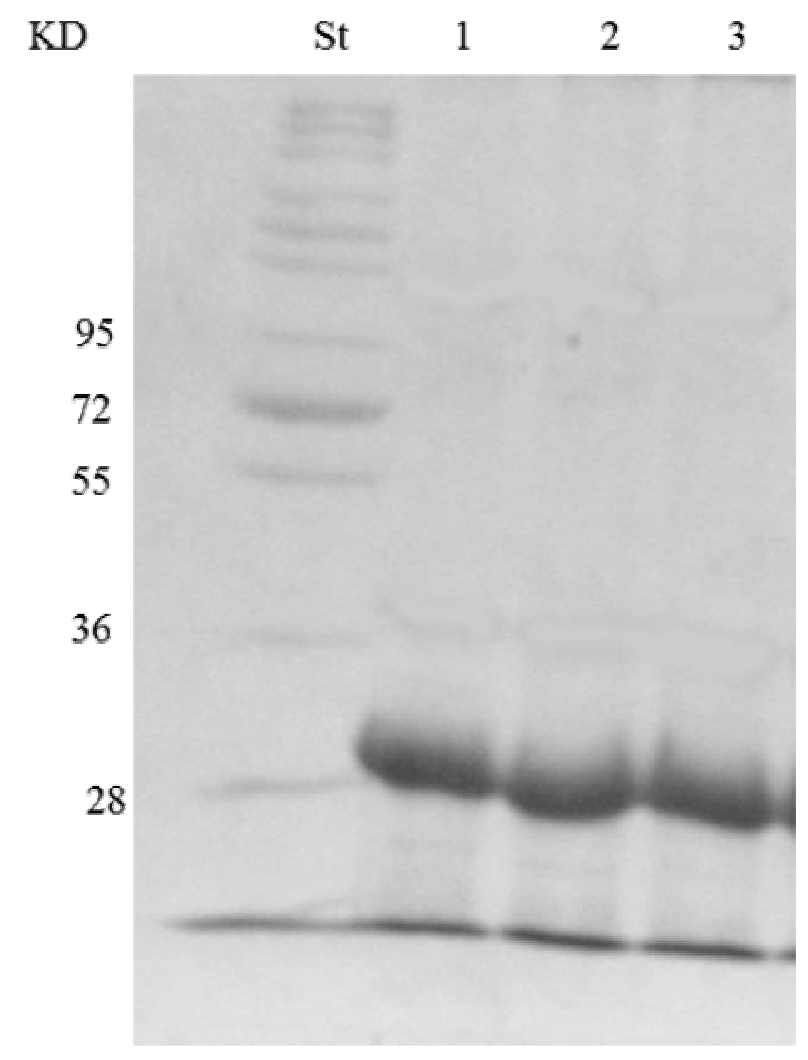

Fig. 1. SDS-PAGE of bacteriocin produced from L. brevis (lane 1), L. plantarum (lane 2) and $L$. fermentum (lane 3) 
Mostafa, et al.

Table 5. Stability of bacteriocin produced by LAB at different pH against two pathogenic bacteria tested by well diffusion assay method

\begin{tabular}{|c|c|c|c|c|c|c|}
\hline \multirow[t]{2}{*}{ pH Bacteria } & \multicolumn{3}{|c|}{$\begin{array}{l}\text { Diameter of the inhibition-zone }(\mathrm{mm}) * \\
\text { against } E \text {. coli } \\
\end{array}$} & \multicolumn{3}{|c|}{$\begin{array}{c}\text { Diameter of the inhibition-zone (mm) } \\
\text { against Staph. aureus }\end{array}$} \\
\hline & L. brevis & L. plantarum & L. fermentum & L. brevis & L. plantarum & L. fermentum \\
\hline 3 & 4 & 3 & 3 & 3 & 4 & 4 \\
\hline 4 & 5 & 6 & 4 & 5 & 6 & 6 \\
\hline 5 & 22 & 23 & 22 & 23 & 21 & 21 \\
\hline 6 & 29 & 26 & 26 & 29 & 23 & 25 \\
\hline 7 & 27 & 25 & 25 & 28 & 22 & 23 \\
\hline 8 & 24 & 21 & 20 & 23 & 20 & 19 \\
\hline 9 & 14 & 15 & 14 & 15 & 15 & 14 \\
\hline 10 & 8 & 7 & 7 & 8 & 7 & 8 \\
\hline 11 & 5 & 4 & 5 & 5 & 5 & 4 \\
\hline
\end{tabular}

L. :Lactobacillus E.: Esherichia Staph.: Staphylococcus *: Inhibition zone around the well <5mm: No inhibition $\begin{array}{lll}\text { 5-10 mm: Low inhibition } & \text { 11-20: Moderate inhibition }\end{array}$

Table 6. Stability of bacteriocin producd by LAB at different heat treatments against two pathogenic bacteria tested by well diffusion assay method

\begin{tabular}{|c|c|c|c|c|c|c|}
\hline \multirow[b]{2}{*}{ Temperature $\left({ }^{\circ} \mathrm{C}\right)$} & \multicolumn{3}{|c|}{$\begin{array}{l}\text { Diameter of the inhibition-zone } \\
(\mathrm{mm}) * \text { against } E \text {. coli }\end{array}$} & \multicolumn{3}{|c|}{$\begin{array}{l}\text { Diameter of the inhibition-zone } \\
(\mathrm{mm}) * \text { against Staph. aureus }\end{array}$} \\
\hline & L. brevis & L. plantarum & L. fermentum & L. brevis & L. plantarum & L. fermentum \\
\hline$\overline{30^{\circ} \mathrm{C}, 30 \mathrm{~min} .}$ & 29 & 26 & 26 & 29 & 23 & 25 \\
\hline $40^{\circ} \mathrm{C}, 30 \mathrm{~min}$. & 28 & 26 & 26 & 29 & 23 & 25 \\
\hline $50^{\circ} \mathrm{C}, 30 \mathrm{~min}$. & 25 & 22 & 23 & 26 & 21 & 23 \\
\hline $60^{\circ} \mathrm{C}, 30 \mathrm{~min}$. & 24 & 21 & 23 & 26 & 20 & 21 \\
\hline $70^{\circ} \mathrm{C}, 30 \mathrm{~min}$. & 21 & 19 & 19 & 22 & 20 & 19 \\
\hline $80^{\circ} \mathrm{C}, 30 \mathrm{~min}$. & 18 & 16 & 17 & 20 & 18 & 17 \\
\hline $90^{\circ} \mathrm{C}, 30 \mathrm{~min}$. & 11 & 12 & 12 & 14 & 12 & 13 \\
\hline $100^{\circ} \mathrm{C}, 30 \mathrm{~min}$. & 8 & 7 & 8 & 9 & 8 & 7 \\
\hline Autoclaving $\left(121^{\circ} \mathrm{C}, 15 \mathrm{~min}.\right)$ & 5 & 4 & 4 & 6 & 5 & 5 \\
\hline
\end{tabular}

L. :Lactobacillus E.: Esherichia Staph.: Staphylococcus *: Inhibition zone around the well < $\quad$ mm: No inhibition $\begin{array}{lll}5-10 \mathrm{~mm} \text { : Low inhibition } & \text { 11-20: Moderate inhibition }\end{array}$ 
The bacteriocin produced from $L$. brevis was found to be stable from $\mathrm{pH} 5$ to 8 and thermostable up to $70^{\circ} \mathrm{C}$ with a partial loss in activity at $80^{\circ} \mathrm{C}$. L. plantarum was found to be active at wide $\mathrm{pH}$ range from 5 to 8 and active at wide range of temperatures from $30^{\circ} \mathrm{C}$ to $70^{\circ} \mathrm{C}$ for $30 \mathrm{~min}$. Bacteriocin produced by L. fermentum was stable up to $70^{\circ} \mathrm{C}$ for $30 \mathrm{~min}$. and $\mathrm{pH}$ 5-8 which showed higher inhibition activity. These results confirm those obtained by Sankar et al. (2012), Radha and Tallapragada (2015), Seema et al. (2015) and Sahar et al. (2017).

\section{Effect of Surfactants and Detergents on Bacteriocin Activity}

Surfactants and detergents were used to study the bacteriocin activity profile. The MRS- broth was supplemented with SDS, EDTA and Tween $80(0.5 \% V / V$ final concentration). From Table 7 , it is noted that Tween $80(0.5 \% \quad V / V)$ improved bacteriocin activity produced from $L$. brevis, L. plantarum and L. fermentum and similar results were obtained with EDTA and SDS. Tween 80 supported the maximum bacteriocin activity of $33 \mathrm{~mm}$ inhibition zone by $L$. brevis against $E$. coli. These results are in line with those found by Sahar et al. (2007); Ogunbanwo et al. (2003) as well as Radha and Tallapragada (2015).

Amino Acids Composition of the Bacteriocins Produced by $L$. brevis, L. plantarum and L. fermentum

The amino acids composition of lactic acid bacteria (L. brevis, L. plantarum and L. fermentum) obtained by gel chromatography are listed in
Table 8. The contents of the hydrophobic amino acids residues (Pro, Gly, Ala, Val, Ile, Leu, Phe) are $0.92 \%, 0.83 \%$ and $0.92 \%$ for $L$. brevis, L. plantarum and L. fermentum, respectively. The contents of the acidic amino acid residues (Asp $+\mathrm{Glu}$ ) are $0.74 \%$ for all tested samples while the contents of the basic amino acids (Arg + Lys + His) are $0.23 \%$ for all tested samples. The antibacterial properties of proteins are dependent on their interaction with the bacterial cell wall and membranes via hydrophobic and electrostatic interaction (Hancock, 2004). Positively charge protein electrostatically bind to lipopolysaccharides on the outer membrane of gram negative bacteria or lipoteichoic acids on the surfaces of gram positive bacteria (Glinel et al., 2012).

\section{Conclusion}

Lactobacillus spp. are non-pathogenic, useful lactic acid bacteria. They produce secondary metabolites termed bacteriocins which are used as anti-microbial agents, which inhibited the growth of both Gram-positive and Gramnegative pathogenic thus exhibiting broad spectrum inhibition. The produced bacteriocin could withstand varied temperatures and $\mathrm{pH}$ treatments which is a novel characteristic of a protein to be explored as a food preservative (bio preservative). It was found to be stable at higher temperatures which makes it feasible to be used in liquid and solid foods which needs to be pasteurised before consumption, for example ready to eat foods. The bacteriocin can be used as a bio preservative in different foods from highly acidic foods such as fruit juices to vegetables which are alkaline.

Table 7. Effect of surfactants and detergents on the activity of bacteriocin produced by LAB strains, which showed inhibition zones of two pathogenic bacteria using well diffusion assay method

\begin{tabular}{ccccccc}
\hline & $\begin{array}{c}\text { Bacteria } \\
\text { Detergents }\end{array}$ & \multicolumn{2}{c}{$\begin{array}{c}\text { Diameter of the inhibition-zone } \\
(\mathbf{m m}) \text { aganist } \boldsymbol{E} \text {. coli }\end{array}$} & $\begin{array}{c}\text { Diameter of the inhibition-zone } \\
(\mathbf{m m}) \text { aganist Staph. aureus }\end{array}$ \\
\cline { 2 - 7 } & L. brevis & L. plantarum & L. fermentum & L. brevis L. plantarum L. fermentum \\
\hline SDS & 31 & 28 & 29 & 30 & 28 & 28 \\
EDTA & 32 & 28 & 29 & 31 & 29 & 28 \\
Tween 80 & 33 & 29 & 30 & 32 & 29 & 29 \\
\hline
\end{tabular}

L. :Lactobacillus E.: Esherichia Staph.: Staphylococcus *: Inhibition zone around the well <5mm: No inhibition 5-10 mm: Low inhibition 11-20: Moderate inhibition 20-30 mm: High inhibition 
Table 8. Comparison of amino acids composition of the bacteriocins produced by $L$. brevis, L. plantarum and L. fermentum

\begin{tabular}{|c|c|c|c|c|c|c|c|c|c|c|c|c|c|c|c|c|c|}
\hline $\begin{array}{c}\text { Amino acid } \\
\mathrm{g} / 100 \mathrm{ml}\end{array}$ & 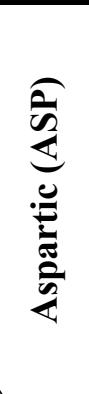 & 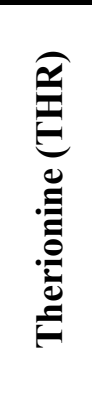 & 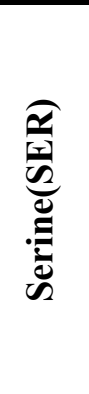 & 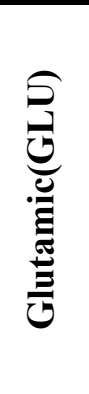 & 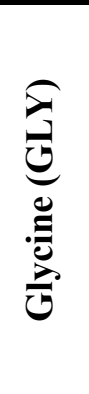 & 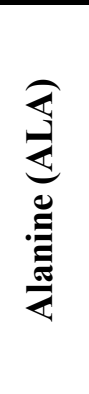 & 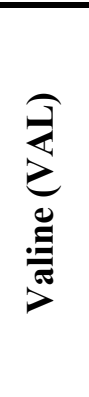 & 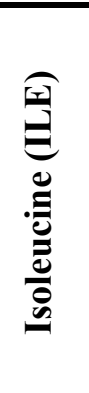 & 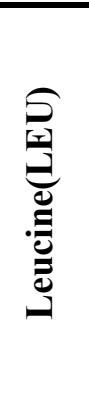 & 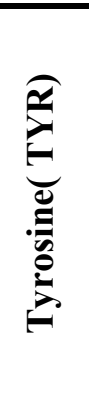 & 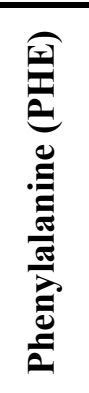 & 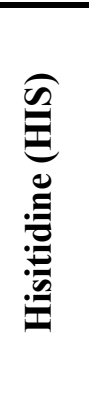 & 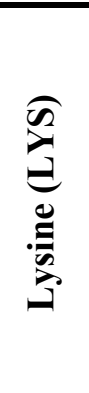 & 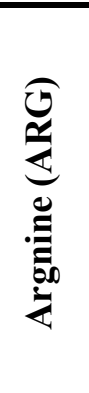 & 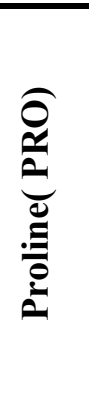 & 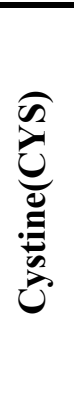 & \\
\hline L. brevis & 0.14 & 0 . & 0.10 & $\overline{0.6}$ & $\overline{0.1}$ & 0.12 & 0.13 & $\overline{0 .}$ & 0.17 & 0.08 & 0 & .04 & $\overline{0}$ & 5 & 0.26 & 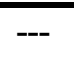 & . \\
\hline L. plantarum & 0.14 & 0.08 & 0.10 & 0.60 & 0.11 & 0.13 & 0.13 & 0.10 & 0.17 & 0.08 & 0.11 & 0.04 & 0.13 & 0.06 & 0.26 & -- & --- \\
\hline L. fermentum & 0.14 & 0.08 & 0.10 & 0.60 & 0.11 & 0.13 & 0.13 & 0.10 & 0.17 & 0.08 & 0.12 & 0.04 & 0.14 & 0.06 & 0.26 & -- & --- \\
\hline
\end{tabular}

\section{REFERENCES}

Bernet, M.F., D. Brassart, J.R. Meeser and A.L. Servin (1994). Lactobacillus acidophilus LA1 binds to cultured human intestinal cell lines and inhibits cell-attachment and cellinvasion by enterovirulent bacteria. Gut., 35 : 483-489.

Biswass, S. and J.M. Rolain (2013). Use of MALDI-TOF mass spectrometry for identification of bacteria that are difficult to culture. J. Microbiol. Meth., 92:14-24.

Bizzini, A., C. Durussel, J. Bille, G. Greub and G. Prod'hom (2010). Performance of matrixassisted laser desorption ionization-time of flight mass spectrometry for identification of bacterial strains routinely isolated in a clinical microbiology laboratory. J. Clin. Microbiol., 48:1549-1554.

Carbonnelle, E., P. Grohs, H. Jacquier, N. Day, S. Tenza, A. Dewailly, O. Vissouarn, M. Rottman, J.-L. Herrmann, I. Podglajen and L. Raskine (2012). Robustness of two MALDITOF mass spectrometry systems for bacterial identification. J. Microbiol. Methods, 89: 133-136. http://dx.doi.org/10.1016/j.mimet. 2012.03.003.

Chalupová, J., M. Raus, M. Sedlářová and M. Šebela (2014). Identification of fungal microorganisms by MALDI-TOF mass spectrometry. Biotechnol. Adv., 32: 230241. http://dx. doi.org/10.1016/j.biotechadv. 2013.11.002.

De-Man, J.C., M. Rogosa and E. Sharpe (1960). Medium of lactobacilli. J. Appl. Bacteriol., 23: 130-135.

Dušková, M., O. Šedo, K. Kšicová, Z. Zdráhal and R. Karpiššvóa (2012). Identification of lactobacilli isolated from food by genotypic methods and MALDI-TOF MS. Int. J. Food Microbiol., 159, 107-114.http://dx.doi.org/ 10. 1016/j.ijfoodmicro.2012.07.029.

Ennahar, S., K. Sonomoto and A. Ishizaki (1999). Class IIa bacteriocins from lactic acid bacteria: antibacterial activity and food preservation. J. Biosci. and Bioeng., 87 (6): . 705-716.doi:10.1016/S1389-1723(99) 80142-X

Fricourt, B.V., S.F. Barefoot, R.F. Testin and S.S. Haysaka (1994). Detection and activity of plantaricin $\mathrm{F}$ an antimicrobial substance from Lactobacillus plantarum BF001 isolated from processed channel catfish. J. Food Prot., 57: 698-702.

Garneau, S., N.I. Martin and J.C. Vederas (2002). Two-peptide bacteriocins produced by lactic acid bacteria. Biochem., 84: 577592.

Glinel, K., P. Thebault, V. Humblot, C.M. Pradier and T. Jouenne (2012). Antibacterial surfaces developed from bio-insired approaches. ActaBiomater., 8: 1670-1684. 
Hancock, R.E.W. (2004). Bacterial Structure and Physiology: Influence on Susceptibility to Cationic Antimicrobial Peptides. In: B.A. Devine and R.E.W. Hancock (eds.), Mammalian Host Defense Peptides (229244). Cambridge, UK: Camb. Univ. Press.

Ivanova, I., P. Kabadjova, A. Pantev, S. Danova and X. Dousset (2000). Detection, purification and partial characterization of a novel bacteriocin substance produced by Lactococcus lactis subsp. lactis b14 isolated from Boza-Bulgarian traditional cereal beverage. Biocatalysis, 41(6): 47-53.

Karaoğlu, A.S., A. Faruk, S.S. Kiliç and A.O. Kiliç (2003). Antimicrobial activity and characteristics of bacteriocins produced by vaginal Lactobacilli, Turkish J. Med. Sci., 33 (1): 7-13.

Klaenhammer, T.R. (1988). Bacteriocins of lactic acid bacteria. Biochem., 70: 337-349.

Laemmli, U.K. (1970). Cleavage of structural proteins during assembly of the head of bacteriophage. Nat., $227: 680-685$.

Logan, N.A. and P. De Vos (2009). Genus 1Bacillus Cohn 1872. In: Bergey's Manual of Systematic Bacteriology, (Eds.) Vos,P.D., Garrity, G., Jones, D., Krieg, N.R., Ludwig, W., Rainey, F.A., Schleifer, K.H., Whitman , W.B. Volume 3: The Firmicutes, Springer, 21-127.

Mortvedt, J.J., F.R. Cox, L.M. Shuman and R.M. Welch (1991). Micronutrients in Agriculture, $2^{\text {nd }}$ Ed., Soil Sci. Soc. Ame., Madison.

Motta, A.S. and A. Brandelli (2002). Characterization of an antibacterial peptide produced by Brevibacterium lines. J. Appl. Microbiol., 92: 63-70.

Nacef, M., M. Chevalier, S. Chollet, D. Drider and C. Flahaut (2016). MALDI-TOF mass spectrometry for the identification of lactic acid bacteria isolated from a French cheese: The Maroilles. Int. J. Food Microbiol., 1-7.

Ogunbanwo, S.T., A.I. Sanni and A.A. Onilude (2003). Characterization of bacteriocin produced by Lactobacillus plantarum $\mathrm{F} 1$ and
Lactobacillus brevis OGI. Afr. J. Biotechnol., 2 :219-227.

Osman, A., H.A. Goda and M. Sitohy (2018). Storage stability of minced beef supplemented with chickpea legumin at $4^{\circ} \mathrm{C}$ as a potential substitute for nisin. LWT, 93: 434-441.

Parada, J.L., R.C. Carolina, B.P.A. Medeiros and R.S. Carlos (2007). Bacteriocins from lactic acid bacteria: Purification, properties and use as bio preservatives. Braz. Arch. Biol. Technol., 50 (3): 521-542.

Radha, K.R. and P. Tallapragada (2015). Purification, characterization and application of bacteriocin for improving the shelf-life of sprouts: An approach to Bio preservation. Dept. of Microbiology, Centre for Post Graduate Studies, Jain Univ., 18/3, $9^{\text {th }}$ main, $3^{\text {rd }}$ block Jayanagar, Bangalur, Karnataka, India, 8 (8): 265-277.

Ravi, V., M. Prabhu and D. Subramanyam (2011). Isolation of bacteriocin producing bacteria from mango pulp and its antimicrobial activity. J. Microbiol. Biotech. Res., 1 (2): 54-63.

Ravi, S.N., V.D. Priyanka, P.S. Reddy, P. Rajanikanth, V.K. Kumar and M. Indira (2012). Purification and characterization of bacteriocin produced by Lactobacillus plantarum isolated from cow milk. Int. J. Microbiol. Res., 3 (2): 133-137.

Sahar, F.D., H. Martin, N.K. Eva, L. Sara, A.K. Ashraf and M. Bo (2007). Production and physicochemical characterization of acidocin D20079, a bacteriocin produced by Lactobacillus acidophilus D20079. World J. Microbiol. Biotech., 23:911-921.

Sahar, A., J.S. Tan, T.A.T. Ibrahim, F. Bashokouh, N.R. Ramakrishnan, S. Mustafa and A.B. Ariff (2017). Fermentation factors influencing the production of bacteriocins by lactic acid bacteria.Rev. RSC Adv.7, 29395. DOI: $10.1039 / \mathrm{c} 6 \mathrm{ra} 24579 \mathrm{j}$

Sankar, N.R., V.D. Priyanka, P.S. Reddy, P. Rajanikanth, V.K. Kumar and M. Indira (2012). Purification and characterization of bacteriocin produced by Lactobacillus plantarum isolated from cow milk. Int. J. Microbiol. Res., 3 (2): 133-137. DOI: 10. 5829/idosi.ijmr.2012.3.2.62182. 
Seema, J.P., M. Maithri, P. Dharani, V.A. Praneetha and Yashaswini (2015). Production, purification and characterization of bacteriocins from lactic acid bacteria. Dept. Biotech., GM Inst. Tech., Davangere, Karnataka, India. Int. J. Pure App. Biosci., 3(1): 236-240.

Sgouras, D., P. Maragkoudakis, K. Petraki, B. Martinez-Gonzalez, E. Eriotou, S. Michopoulos, G. Kalantzopoulos, E. Tsakalidou and A. Mentis (2004). In vitro and In vivo inhibition of Helicobacter pylori and Lactobacillus casei strain Shirota. Appl. Environ. Microbiol., 70: 518-526.

Sharma, N., G. Kapoor and B. Neopaney (2006). Characterization of a new bacteriocin produced from a novel isolated strain of Bacillus lentus NG121. Antonie Van Leeuwenhoek, 89 : 337-343.

Sharma, N. and N. Gautam (2007). Use of bacteriocin as potential bio-preservative in milk, cheese and apple juice. Bev. Food World, 34: 44-47.

Simpson, R.J., M.R. Neuberger and T. Liu (1976). Complete amino acid analysis of proteins from a single hydrolysate. J. Biol. Chem., 251: 1936-1940.

Sivaramasamy, E., N. Annamalai, P. Mayavu and T. Balasubramanian (2014). Production, purification and characterization of bacteriocin from Lactobacillus murinus AU06 and its broad antibacterial spectrum. Asian Pac. J. Trop Biomed., 4 (1): 305-311.

Tannock, G.W. (1999). A fresh look at the intestinal microflora. In: Probiotics. A critical review. Ed., Tannock, G.W., Horizon Scientific Press, Norfolk, UK, pp: 5-14.

Vera, P.E., E. Salvucci, F. Seama and M.E. Nader-Macias (2012). Different strategies for purification of antimicrobial peptides from lactic acid bacteria. Commun. Current Res. and Educ. Topics and Trends in App. Microbiol., Formatex, 557-568.

Wang, Y.R., Q. Chen, C.S. Hui and L.F. Qin (2013). Characterization of Staphylococcus aureus isolated from clinical specimens by Matrix Assisted Laser Desorption/Ionization Time-off light Mass Spectrometry. Biomed. Environ. Sci., 26 (6): 430-436.

\section{تنقية ومواصفات البكتريوسين المنتج بواسطة بعض أنواع جنس اللاكتوباسلس المعزولة من الأغذية \\ نادين جمال الاين مصطفى ـ عصام الدين محمود جويلى ـ فاطمه إبر اهيم إلزامك ـ علي سلامهه علي \\ قسم الميكروبيولوجيا الزر اعية ـ كلية الزراعة ـ جامعه الزقازيق ـ مصر لئرئ}

تم عزل • r عزله من بكتيريا حامض اللاكتيك لاهو ائيا من مصادر غذائية مختلفة وهى (الجبن الدمياطىـ اللبن الخام -

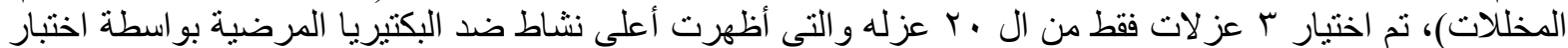
well diffusion assay methods

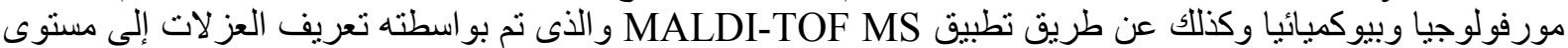
الجنس و النوع، وكانت هذه الأنو اع هي L. brevis, L. fermentum, L. plantarum و التى تم عزل وتئ وتنقيه البكتريوسين

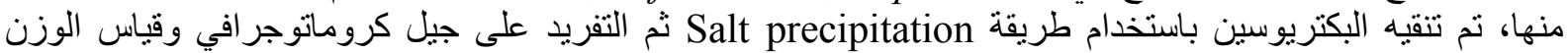

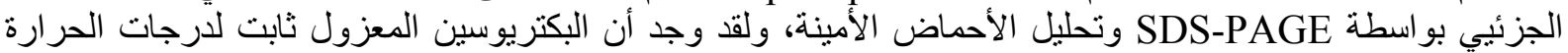

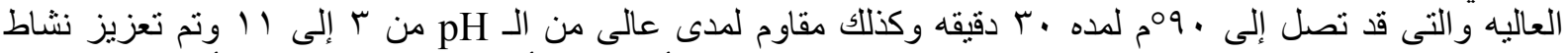

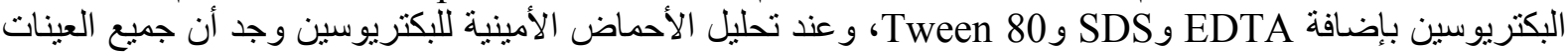

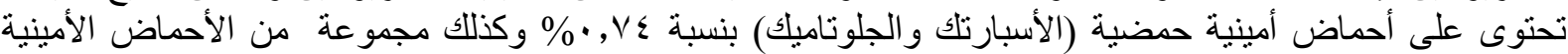

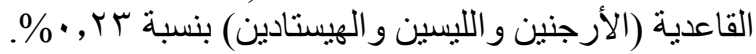

